\section{DcHsp17.7, a Small Heat Shock Protein from Carrot, Is Upregulated under Cold Stress and Enhances Cold Tolerance by Functioning as a Molecular Chaperone}

\author{
Na-Hyun Song and Yeh-Jin Ahn' \\ Department of Green Life Science, College of Convergence, Sangmyung \\ University, 7 Hongji-dong, Jongno-gu, Seoul 110-743, Korea
}

Additional index words. cold stress, Daucus carota L., heat shock protein, molecular chaperone, oligomeric complex

\begin{abstract}
The expression profile and functional properties of DcHsp17.7, a small heat shock protein from carrot (Daucus carota L.), were examined under cold stress. Immunoblot analysis showed that low temperature $\left(2{ }^{\circ} \mathrm{C}\right)$ induced DcHsp17.7 in vegetative tissues. Differential accumulation of the transcript and protein under the cold suggests that expression of DcHsp17.7 might be controlled at the transcriptional and/or translational levels. To examine the functional properties of DcHsp17.7, the gene was expressed in Escherichia coli. When exposed to $2^{\circ} \mathrm{C}$ for 10 days, transformed cells expressing DcHsp17.7 showed $115 \%$ cell viability, whereas control cells recorded $24 \%$, suggesting that DcHsp17.7 can confer cold tolerance. The amount of soluble protein under the cold was $83 \%$ in transformed cells expressing DcHsp17.7, whereas the control cells showed only 52\%, suggesting that DcHsp17.7 functions as a molecular chaperone preventing cold-induced protein degradation. Native-polyacrylamide analysis revealed that DcHsp17.7 was found in two oligomeric complexes $(\approx 160$ and $240 \mathrm{kDa})$ and possibly multiple complexes (from 300 to $450 \mathrm{kDa}$ ) in cold-stressed carrot and transformed $E$. coli, respectively. During prolonged cold stress, these complexes disappeared and then reappeared, suggesting that the dissociation and reassociation of DcHsp17.7 complexes might be important for the function of the protein.
\end{abstract}

All organisms studied to date respond to high temperatures by synthesizing a group of proteins known as heat shock proteins (HSPs). HSPs are divided into five classes based on their molecular weight: HSP100, HSP90, HSP70, HSP60, and small HSPs (sHSPs). sHSPs are $\approx 15$ to $42 \mathrm{kDa}$ in size and are characterized by a conserved $\alpha$-crystallin domain of the vertebrate eye lens at their C-terminus (Haslbeck et al., 2005). In plants, sHSPs are the most abundant and diverse HSPs produced at high temperatures. The induction of sHSPs under heat stress and the correlation between sHSP accumulation and enhanced thermotolerance have been well established in a number of previous studies (Haslbeck et al., 2005; Sun et al., 2002). Furthermore, some sHSPs are also known to be induced by various abiotic stresses such as cold, salinity, drought, and chemical pollution (Vinocur and Altman, 2005).

Cold-induced accumulation of sHSPs and/or their transcripts has been reported in some

\footnotetext{
Received for publication 30 Nov. 2009. Accepted for publication 14 Jan. 2010.

This work was supported by the BioGreen 21 Program Grant (Code \# 20070501034003) funded by the Rural Development Administration, Korea. ${ }^{1}$ To whom reprint requests should be addressed; e-mailyjahn@smu.ac.kr.
}

plant species. An sHSP in sweet chestnut (Castanea sativa L.), CsHsp17.5, was constitutively expressed in stem and was upregulated by both high and low temperatures (Lopez-Matas et al., 2004; Soto et al., 1999). A more recent report showed that a rose sHSP (Rosa chinensis L.) was not expressed in the absence of stress but was induced under a cold stress condition $\left(2^{\circ} \mathrm{C}, 6 \mathrm{~h}\right.$; Jiang et al., 2009). These studies suggest that at least some plant sHSPs may confer cold tolerance.

A number of studies have shown that sHSPs function as molecular chaperones preventing heat-induced protein denaturation and promoting refolding of partially denatured proteins. Some plant sHSPs prevented thermal aggregation of model substrates such as malate dehydrogenase and citrate synthase (Lee et al., 1995, 1997). In vivo, Arabidopsis Hsp17.6 maintained firefly luciferase activity in an Arabidopsis cell suspension culture under heat stress (Forreiter et al., 1997). Under cold stress, which also causes protein denaturation in plant cells (Thomashow, 1999), it is possible that cold-induced sHSPs may function as molecular chaperones enhancing protein solubility. However, the precise functional mechanism of sHSPs under cold stress remains to be studied.

The carrot (Daucus carota L.) sHSP, DcHsp17.7, has been characterized in previous studies. Its constitutive expression enhanced cell viability and membrane stability in transgenic carrot cells and plants under heat stress (Malik et al., 1999). Furthermore, the expression of an antisense construct of the DcHsp17.7 gene resulted in reduced thermotolerance. This was the first demonstration that modification of the expression of a single sHSP can both increase and decrease thermotolerance in plants. When introduced into the cool-season crop potato (Solanum tuberosum L.), DcHsp17.7 enhanced cellular membrane stability and tuberization in vitro (Ahn and Zimmerman, 2006). More recently, heterologous expression of DcHsp17.7 in Escherichia coli showed that it functions as a molecular chaperone preventing aggregation of proteins and enhances cell viability under heat stress (Kim and Ahn, 2009).

In this study, we examined the expression and functional mechanism of DcHsp17.7 under the opposite temperature stress, the cold. DcHsp17.7 transcript and protein levels induced by low temperature were measured using semiquantitative reverse transcription polymerase chain reaction (PCR) and immunoblot analysis, respectively. Furthermore, to study the function of DcHsp17.7, the gene was introduced into E. coli. Under cold stress, cell viability and protein solubility of transformed $E$. coli expressing DcHsp17.7 were compared with those of controls. In addition, cold-induced dynamic association and dissociation of DcHsp17.7 complexes was also observed.

\section{Materials and Methods}

Accumulation of DcHsp17.7 under temperature stresses. Carrot seeds (Daucus carota L. cv. Mussangochon) were sown in a peat-vermiculite growth mixture and tissues from 2- to 3-month-old plants were used. Carrot plants were grown in a controlled environmental chamber $\left(18 / 22{ }^{\circ} \mathrm{C}\right.$, night/ day). Various carrot tissues were treated at high $\left(40^{\circ} \mathrm{C}\right)$ and low $\left(2^{\circ} \mathrm{C}\right)$ temperatures and immunoblot analysis was performed as previously described (Ahn et al., 2004). Briefly, proteins were obtained by homogenizing tissues in extraction buffer $(0.3 \%$ SDS, 200 mm DTT, $28 \mathrm{~mm}$ Tris- $\mathrm{HCl}$, and $22 \mathrm{~mm}$ Tris base) and quantified using a Bradford assay (Bradford, 1976). Equal amounts $(40 \mu \mathrm{g})$ of protein were resolved on a $12 \%$ sodium dodecyl sulphate-polyacrylamide (SDS-PAGE) gel and electroblotted to polyvinylidene difluoride membrane (Bio-Rad, Hercules, CA). Immunoblot analysis was performed using a polyclonal antibody raised against DcHsp17.7 according to the instructions of the ECL Plus system (Amersham Biosciences, Pittsburgh, PA). To quantify the expression profile of DcHsp17.7 in cold-stressed leaves, chemiluminescent signals were measured using IMAGER and 1D MAIN (Bioneer, Daejeon, Korea). The values were normalized to the expression level at $1 \mathrm{~d}$.

Accumulation of DcHsp17.7 transcripts under cold stress. The transcript level of the DcHsp 17.7 gene was analyzed semiquantitatively using reverse transcription PCR. Total 
Leaf

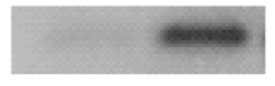

C $\quad 40^{\circ} \mathrm{C}$

B. Cold stress

Leaf

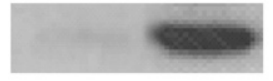

C
Stem

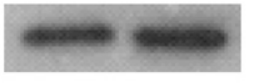

C $\quad 40^{\circ} \mathrm{C}$

Stem

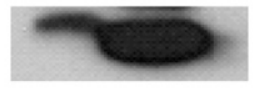

C $\quad 2{ }^{\circ} \mathrm{C}$
Root

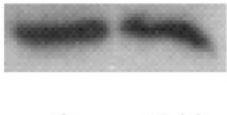

C $\quad 40^{\circ} \mathrm{C}$

Root

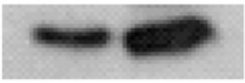

C $\quad 2{ }^{\circ} \mathrm{C}$

Fig. 1. Accumulation of DcHsp17.7 at high and low temperatures. Carrot tissues from 2- to 3-month-old plants were treated at high $\left(\mathbf{A}, 40^{\circ} \mathrm{C}, 8 \mathrm{~h}\right)$ and low $\left(\mathbf{B}, 2^{\circ} \mathrm{C}, 3 \mathrm{~d}\right)$ temperatures. Equal amounts of protein $(40 \mu \mathrm{g})$ were subjected to sodium dodecyl sulphate-polyacrylamide $(12 \%)$. Immunoblot analyses were performed using a polyclonal antibody raised against DcHsp17.7. The molecular weight of the band was $\approx 18 \mathrm{kDa}$. C: Nonstressed tissue.

\section{DcHsp17.7}

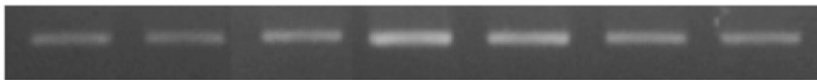

Actin
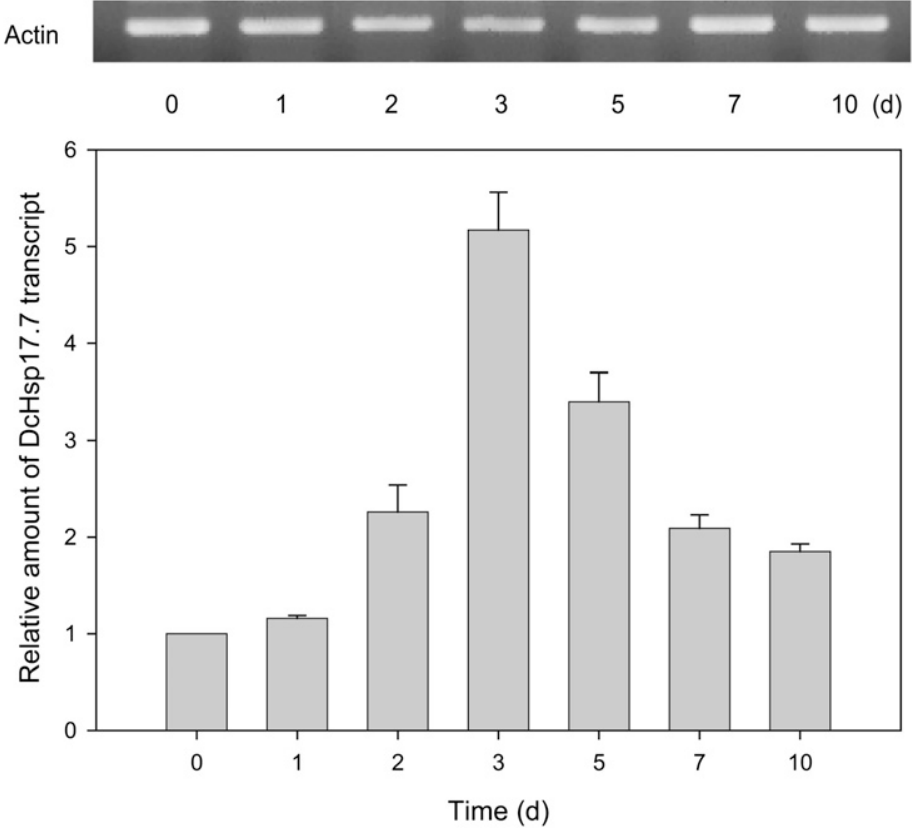

Fig. 2. Expression profile of the $D c H s p 17.7$ gene under cold stress. Semiquantitative reverse transcription polymerase chain reaction (PCR) was performed using RNA from cold-stressed $\left(2{ }^{\circ} \mathrm{C}\right.$ up to $\left.10 \mathrm{~d}\right)$ carrot leaf tissue. Approximately $1 \mu \mathrm{g}$ of RNA was reverse-transcribed and DcHsp17.7 cDNA was amplified by PCR using a set of primers specific to the coding sequence. As a control, part of actin cDNA was also amplified in a parallel experiment. After gel electrophoresis, signals observed under ultraviolet light were quantified. The ratio of DcHsp17.7 cDNA to actin cDNA at $0 \mathrm{~d}$ was given an arbitrary value of 1 . SES of the means were indicated.

RNA was isolated from cold-stressed $\left(2{ }^{\circ} \mathrm{C}\right.$, up to $10 \mathrm{~d}$ ) carrot leaf tissues using the Plant RNA Extraction Kit (Intron, Seoul, Korea). Reverse-transcription was performed by adding $\approx 1 \mu \mathrm{g}$ of RNA to CycleScript RT PreMix (Bioneer). Then, to amplify the DcHsp17.7 cDNA, PCR $\left(1\right.$ cycle at $94{ }^{\circ} \mathrm{C}$ for $5 \mathrm{~min}$ followed by 30 cycles of $94{ }^{\circ} \mathrm{C}$ for $40 \mathrm{~s}, 58{ }^{\circ} \mathrm{C}$ for $50 \mathrm{~s}$, and $72{ }^{\circ} \mathrm{C}$ for $50 \mathrm{~s}$ ) was performed using a set of primers (forward: $5^{\prime}$-GGGGG GCATATGTCGATCATTCCAAGC-3', re- verse: 5' -GGG GGGGCTAGCTTAACCAG AAATATCAATGGC- $\overline{-3^{\prime} \text { ) that }}$ contains an NdeI restriction enzyme site (underlined) overlapping the start codon of the DcHsp 17.7 coding sequence and a NheI restriction enzyme site (underlined) after the stop codon. This primer set was also used for the cloning of DcHsp17.7 for recombinant expression as described subsequently. In a parallel experiment, a set of primers (forward: 5'-GGGAA TGGAGTCTGCTGGAATCCATGA-3', re- verse: 5-GGACCTGATTCGTCATATTCA CCCTTCG-3') was used to amplify a fragment of the actin gene in carrot (NCBI accession number X17525) as a control through PCR ( 1 cycle at $94{ }^{\circ} \mathrm{C}$ for $5 \mathrm{~min}$ followed by 35 cycles of $94^{\circ} \mathrm{C}$ for $40 \mathrm{~s}, 68^{\circ} \mathrm{C}$ for $50 \mathrm{~s}$, and $72{ }^{\circ} \mathrm{C}$ for $50 \mathrm{~s}$ ). To quantify the levels of DcHsp17.7 cDNA, signals observed under ultraviolet light were measured using IMAGER and 1D MAIN (Bioneer). The ratio of DcHsp17.7 cDNA in comparison with actin cDNA at $0 \mathrm{~d}$ was given an arbitrary value of 1 .

Generation of transformed E. coli expressing DcHsp 17.7. DNA construct generation and transformation into E. coli were performed as previously described (Kim and Ahn, 2009). Briefly, the coding region of the DcHsp17.7 gene (NCBI accession number X53851) was amplified through PCR using the set of primers described previously. The amplicon was inserted into the pET11a expression vector (Novagen, Madison, WI). After confirming the sequence, the resulting pET11a-DcHsp 17.7 recombinant vector was introduced into $E$. coli BL21 (DE3; Novagen).

E. coli cell culture and expression of DcHsp17.7 were performed as previously described (Kim and Ahn, 2009). Control cells containing unmodified $\mathrm{pET} 11 \mathrm{a}$ vector and transformed cells containing pET11aDcHsp17.7 vector were cultured in LuriaBertani (LB) broth containing $100 \mu \mathrm{g} \cdot \mathrm{mL}^{-1}$ ampicillin overnight with shaking at $37{ }^{\circ} \mathrm{C}$. Overnight cultures were diluted 1:1000 with fresh LB broth containing ampicillin and continuously incubated at $37{ }^{\circ} \mathrm{C}$. When cell cultures were grown to an $\mathrm{OD}_{600}$ of 0.6 , isopropyl b-D-thiogalactopyranoside (IPTG) was added to a final concentration of $1 \mathrm{~mm}$ to induce the expression of DcHsp17.7. After $2 \mathrm{~h}$ of IPTG treatment, bacterial cells were transferred to a $2{ }^{\circ} \mathrm{C}$ incubator and cultured up to $10 \mathrm{~d}$. Total proteins were extracted using a commercial kit (SMART Bacterial Protein Extraction Solution; Intron) and quantified using a Bradford assay (Bradford, 1976). Equal amounts of protein $(25 \mu \mathrm{g})$ were subjected to SDS-PAGE (12\%). Immunoblot analysis was performed using a polyclonal antibody raised against DcHsp17.7 as described previously.

Cold tolerance of transformed E. coli expressing DcHsp17.7. Overnight cell culture and IPTG treatment were performed as described previously. At $2 \mathrm{~h}$ after IPTG treatment, samples were diluted 1:1000 and plated on LB medium containing ampicillin and IPTG (five plates per time point). Plates were subjected to cold stress $\left(2^{\circ} \mathrm{C}\right)$ up to $10 \mathrm{~d}$ followed by incubation at $37{ }^{\circ} \mathrm{C}$ overnight. Then, the number of surviving colonies was counted.

Molecular chaperone function of DcHsp17.7 under cold stress. The effect of DcHsp17.7 on preventing cold-induced protein denaturation was examined according to the protocol of Soto et al. (1999). Briefly, overnight cell cultures and IPTG treatment were performed as described previously. After $2 \mathrm{~h}$, cell cultures were transferred to $2{ }^{\circ} \mathrm{C}$. An equal number of 

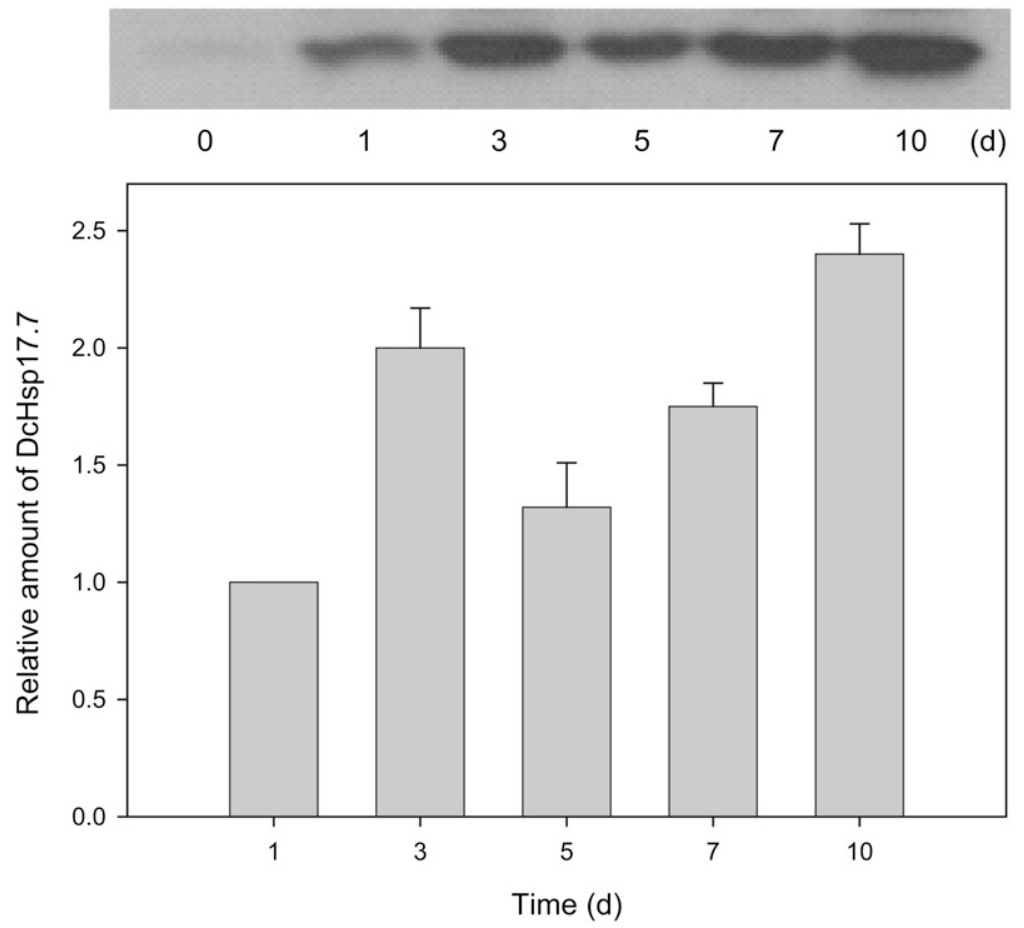

Fig. 3. Accumulation profile of DcHsp17.7 under cold stress. Proteins were extracted from cold-stressed $\left(2{ }^{\circ} \mathrm{C}\right.$ up to $\left.10 \mathrm{~d}\right)$ carrot leaf tissue. Equal amounts of protein $(40 \mu \mathrm{g})$ were subjected to SDS-PAGE $(12 \%)$. Then, immunoblot analysis was performed using a polyclonal antibody raised against DcHsp17.7. The molecular weight of the band was $\approx 18 \mathrm{kDa}$. SES of the means were indicated.

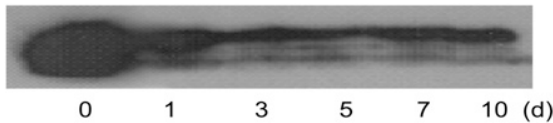

Fig. 4. Heterologous expression of DcHsp17.7 in Escherichia coli. Cell culture and isopropyl b-D-thiogalactopyranoside (IPTG) treatment were performed as described in "Materials and Methods." After $2 \mathrm{~h}$ of IPTG treatment, bacterial cells were transferred to $2{ }^{\circ} \mathrm{C}$ and incubated up to $10 \mathrm{~d}$. At each time point, soluble proteins were extracted and equal amounts of protein $(25 \mu \mathrm{g})$ were subjected to immunoblot analysis using a polyclonal antibody raised against DcHsp17.7. The molecular weight of the band was $\approx 18 \mathrm{kDa}$.

cells $\left(12 \mathrm{~mL}\right.$ per sample at o.d.600 $\left.{ }_{6}=1.2\right)$ was taken at each time point and soluble proteins were extracted as described by Soto et al. (1999). Equal volumes $(22 \mu \mathrm{L})$ of protein samples were separated using SDS-PAGE $(12 \%)$. Soluble proteins were visualized using Coomassie Blue R-250 (Bio-Rad) and quantified by measuring o.d.600 (Bradford, 1976). In addition, the amount of insoluble protein in the pellet fraction was also measured using a Bradford assay after centrifuging protein samples at $16,000 \mathrm{~g}$ for $30 \mathrm{~min}$ (Yeh et al., 1997), and this amount essentially counterbalanced that of the protein in the soluble fraction, indicating that equal amounts of total protein were processed at each time point (data not shown). The experiment was repeated three times.

Complex formation of DcHsp17.7 under cold stress. Protein extraction and immunoblot analysis under native conditions were
St. Louis, MO) just before use. For transformed E. coli expressing DcHsp17.7, cell culture, cold stress treatment, and soluble performed as described previously (Kim and Ahn, 2009). Briefly, proteins from coldwere obtained up to $10 \mathrm{~d}$ ) carrot leaf tiss EDTA, 5\% sucrose, 5\% glycerol, $14.2 \mathrm{~mm}$ -mercaptoethanol, and $0.5 \%$ Triton X-100) treated with Protease inhibitor cocktail for plant cell and tissue extracts (Sigma-Aldrich, protein extraction were performed as described previously. A total of 30 and $25 \mu \mathrm{g}$ of carrot and E. coli proteins, respectively, were resolved on $4 \%$ to $20 \%$ Native-PAGE gels (Bio-Rad). Immunoblot analysis was performed using a polyclonal antibody raised against DcHsp17.7 as described previously.

\section{Results and Discussion}

Accumulation of DcHsp17.7 under both high and low temperature stresses. To study the accumulation pattern of DcHsp17.7 on temperature shift, immunoblot analysis was performed on the proteins from various carrot tissues using a polyclonal antibody raised against DcHsp17.7. DcHsp17.7 was absent or present at a very low level in leaf tissue in the absence of temperature stress (Fig. 1). However, both high $\left(40{ }^{\circ} \mathrm{C}\right)$ and low $\left(2{ }^{\circ} \mathrm{C}\right)$ temperatures induced DcHsp17.7 in the leaf tissue. In stem and root, DcHsp17.7 was constitutively expressed at normal growth temperatures. Temperature shift to $40{ }^{\circ} \mathrm{C}$ did not significantly increase the amount of DcHsp17.7 in either of these tissues (Fig. 1A). However, low temperature did induce the accumulation of the protein (Fig. 1B). Our results showed that the accumulation pattern of DcHsp17.7 is tissue-specific under heat and cold stresses. Under heat stress, sHSP genes are activated by a number of heat-inducible transcription factors (Nover et al., 1996). It is possible that some coldinduced transcription factors can also activate the expression of sHSPs under the cold.

It is worth noting that rather high levels of DcHsp17.7 were detected in stem and root tissues in the absence of thermal stress (Fig. 1). Presence in nonstressed vegetative tissues is not typical for sHSPs, and it has been reported in only a few plant species such as sweet chestnut (Hsp17.5, stem; Lopez-Matas et al., 2004; Soto et al., 1999), sunflower (Hsp17.9 and Hsp17.6, leaf and root; Coca et al., 1994), and Arabidopsis (AtAcd31.2,

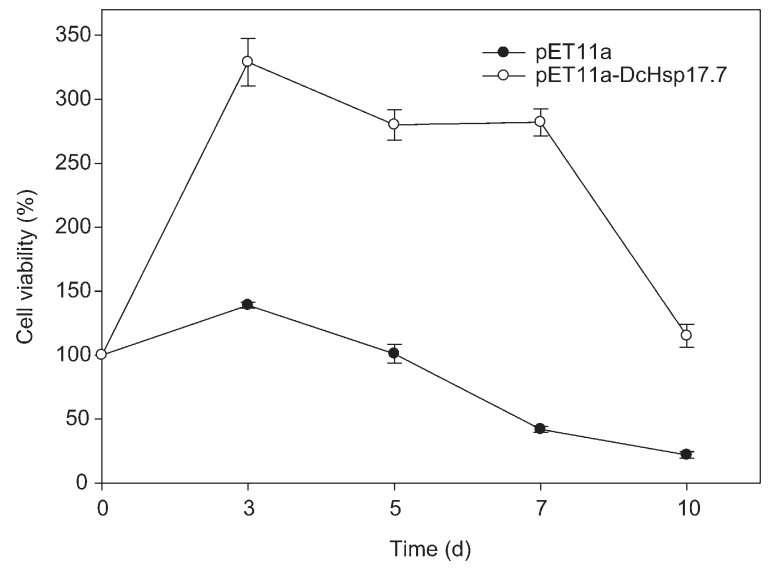

Fig. 5. Enhanced cold tolerance of transformed Escherichia coli expressing DcHsp17.7. Overnight cell culture and isopropyl b-D-thiogalactopyranoside (IPTG) treatment were performed as described in "Materials and Methods." Cell cultures were diluted 1:1000 and plated on Luria-Bertani medium containing ampicillin and IPTG. Plates were then subjected to cold stress $\left(2{ }^{\circ} \mathrm{C}\right)$ for up to $10 \mathrm{~d}$ followed by incubation at $37^{\circ} \mathrm{C}$ overnight. The number of surviving colonies was counted to determine cell viability. 
A.

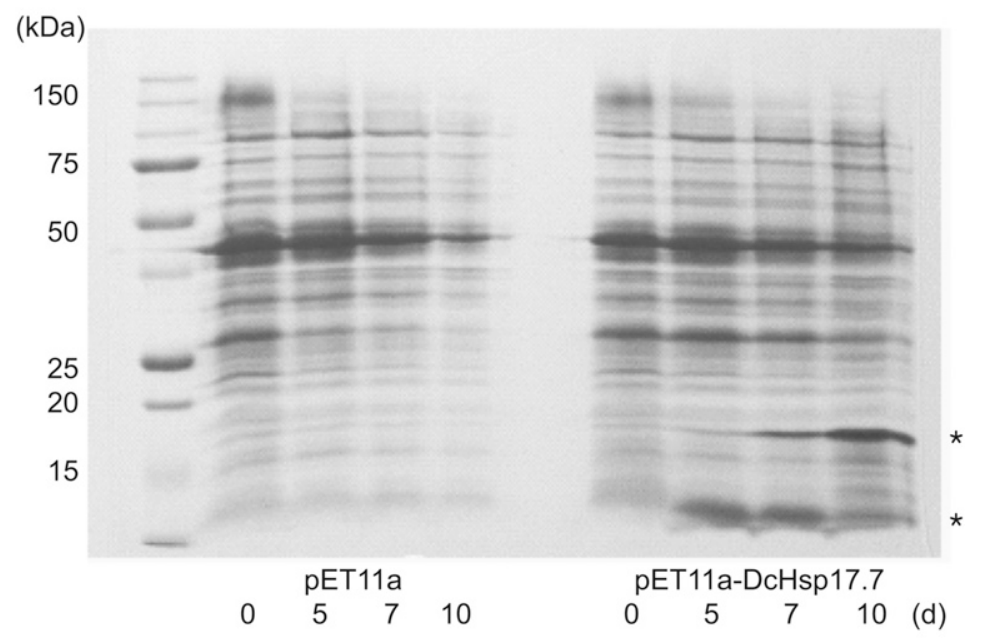

B.

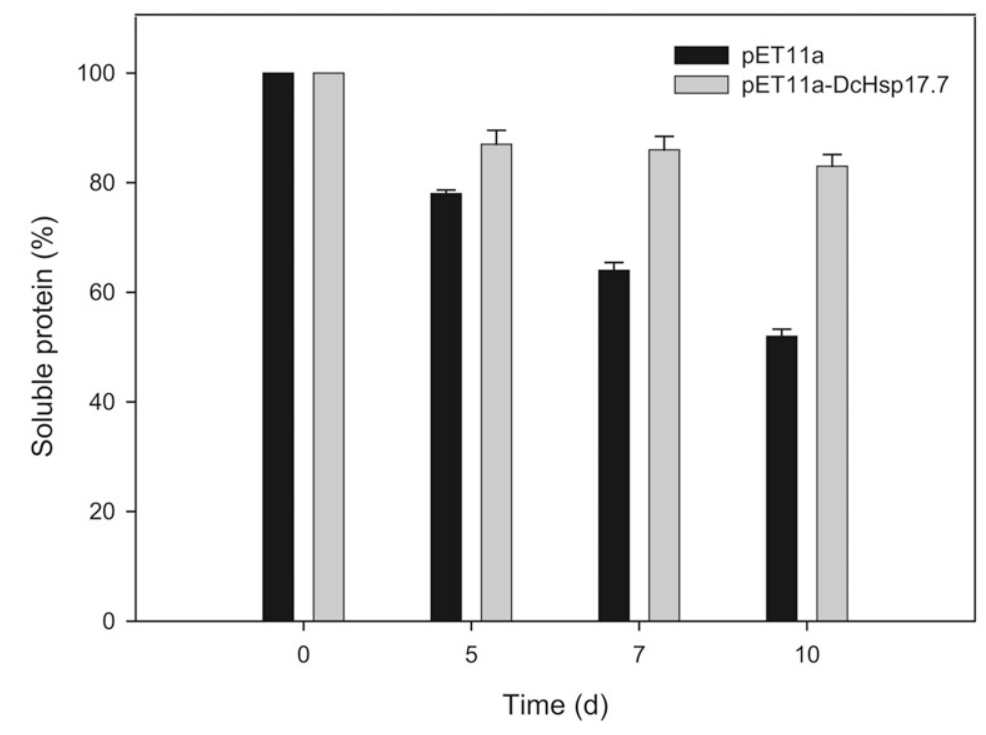

Fig. 6. Molecular chaperone activity of DcHsp17.7 under cold stress. Diluted overnight cell cultures were treated with isopropyl b-D-thiogalactopyranoside as described in "Materials and Methods." After $2 \mathrm{~h}$, cell cultures were transferred to $2{ }^{\circ} \mathrm{C}$. Soluble proteins were extracted from the same number of cells and separated using sodium dodecyl sulphate-polyacrylamide (12\%). (A) Profiles of soluble proteins were visualized using Coomassie Blue. Asterisks denote cold-inducible bacterial proteins that remained soluble only in transformed cells expressing DcHsp17.7 and not in control cells. (B) The amount of soluble protein was quantified using a spectrophotometer and expressed as a percentage of the soluble protein before cold stress.

leaf; Ma et al., 2006). These results suggest that some sHSPs such as DcHsp17.7 may have a role under normal physiological conditions. Alternatively, the presence of sHSPs in the absence of thermal stress may confer advanced protection to sudden temperature changes by immediately enhancing the thermotolerance of cells.

Accumulation profile of DcHsp17.7 transcripts under cold stress. Transcript levels of the DcHsp17.7 gene in cold-stressed carrot leaves were examined using semiquantitative reverse-transcription PCR. As shown in Figure 2, the transcript of DcHsp17.7 was present even in nonstressed leaf tissue. On exposure to the cold, the transcript level increased and reached its maximum level at 3 d (fivefold higher than that before cold treatment). Then, the amount of the transcript decreased until $10 \mathrm{~d}$.

Accumulation profile of DcHsp17.7 under cold stress. The time course of the DcHsp17.7 accumulation induced by low temperature was investigated in leaf tissue. On exposure to cold stress $\left(2^{\circ} \mathrm{C}\right)$, DcHsp 17.7 started to accumulate and the level peaked at $3 \mathrm{~d}$ (twofold higher than that at $1 \mathrm{~d}$; Fig. 3). Then, the level showed a transient but reproducible decline at $5 \mathrm{~d}$ (1.3-fold). However, on continued cold stress, the protein was reinduced and accumulated until $10 \mathrm{~d}$ (2.5-fold). The level of DcHsp17.7 was even slightly higher at $10 \mathrm{~d}$ (during the second upregulation) than at $3 \mathrm{~d}$.

It is worth noting that there was discrepancy between transcript and protein levels. In nonstressed leaf tissue, DcHsp17.7 transcripts accumulated at a significant level (Fig. 2), although the amount of the protein was very small in this tissue (Figs. 1 and 3 ). Second, during prolonged cold stress, the protein level showed a second upregulation reaching its maximum at $10 \mathrm{~d}$ (Fig. 3), but the transcript level continued to decrease at that time point (Fig. 2). These results suggest that the synthesis of DcHsp17.7 might be regulated at the transcriptional and/or translational levels under cold stress. It is possible that carrot leaf cells do not translate most DcHsp17.7 transcripts until thermal stress begins. However, on prolonged cold stress, its transcripts might be translated efficiently to synthesize DcHsp17.7. Alternatively, the discrepancy between the transcript and protein levels during prolonged cold stress might be the result of differential protein stability; it is possible that DcHsp17.7 might not be stable in the absence of thermal stress. However, under prolonged cold stress, the protein might become more stable, resulting in a high level of accumulation. Further study is required to examine the precise regulatory mechanism of HSP synthesis under thermal stress.

Heterologous expression of DcHsp17.7 in E. coli. The coding sequence of DcHsp17.7 was introduced into $E$. coli to examine its functional properties under cold stress. $E$. coli has been used as a convenient system in a number of studies examining properties of plant sHSPs (Kim and Ahn, 2009; Soto et al., 1999; Yeh et al., 1997). First, to confirm the accumulation of DcHsp17.7 in the transformed $E$. coli, immunoblot analysis was performed using a polyclonal antibody raised against DcHsp17.7. As shown in Figure 4, DcHsp17.7 accumulated in the transformed E. coli containing pET11a-DcHsp17.7 recombinant vector after IPTG treatment. However, on storage in the cold, the amount of DcHsp17.7 decreased, possibly as a result of a slower rate of IPTG induction of the recombinant gene under cold stress (Kang et al., 2003). Alternatively, it is also possible that some of the recombinant DcHsp17.7 degrades on exposure to the stress. Low levels of the protein were present up to $10 \mathrm{~d}$ in the cold. In addition, immunoblot analysis performed before IPTG treatment did not show any leaky expression (data not shown).

Enhanced cold tolerance of transformed E. coli expressing DcHsp 17.7. Our previous study showed that heterologous expression of DcHsp17.7 increases heat tolerance in E. coli (Kim and Ahn, 2009). To examine if recombinant DcHsp17.7 can also confer cold tolerance, transformed cells expressing DcHsp17.7 were subjected to $2{ }^{\circ} \mathrm{C}$ for up to $10 \mathrm{~d}$ and cell viability was measured by counting colony-forming units. Under the cold stress condition, cell viability was much higher in transformed cells expressing DcHsp17.7 than in control cells throughout the course of the experiment (Fig. 5). After $3 \mathrm{~d}$ in the cold, transformed cells expressing DcHsp17.7 grew to $329 \%$ in cell viability compared with before the cold treatment. On the other hand, the viability of the control 
cells only increased to $139 \%$ at the same time point. Thereafter, both types of cells started losing viability on prolonged storage in the cold. However, at $10 \mathrm{~d}$, transformed cells expressing DcHsp17.7 still showed 115\% viability, similar to the starting cell count before the cold treatment, whereas only $22 \%$ of the control cells remained alive. Considering the relatively low level of DcHsp 17.7 in transformed E. coli during cold stress (Fig. 4), DcHsp17.7 may function very efficiently to enhance the cold tolerance of bacterial cells.

Molecular chaperone activity of DcHsp17.7 under cold stress. Our previous report showed that DcHsp17.7 functions as a molecular chaperone preventing heat-induced protein denaturation (Kim and Ahn, 2009). In this study, we examined if the protein also functions as a molecular chaperone under cold stress. After cold treatment, soluble proteins were extracted from similar numbers of bacterial cells and quantified. SDS-PAGE analysis of soluble proteins confirmed that protein denaturation was delayed in the transformed cells expressing DcHsp17.7 compared with control cells (Fig. 6A). In addition, DcHsp17.7 protected some bacterial proteins (10 and $17 \mathrm{kDa}$ in size) from cold-inducible denaturation. When quantified, the level of soluble protein was higher in transformed cells expressing DcHsp17.7 than in control cells (Fig. 6B). At $10 \mathrm{~d}$, the former maintained $83 \%$ of the protein soluble. However, only $52 \%$ of the protein remained soluble in the control cells. Our results showed that DcHsp17.7 functions as a molecular chaperone preventing protein denaturation not only under heat stress (Kim and Ahn, 2009), but also under cold stress.

There are only a few studies reporting molecular chaperone function of plant sHSPs under cold stress. In vitro, Lopez-Matas et al. (2004) reported that purified CsHsp17.5, a cytosolic sHSP from sweet chestnut (Castanea sativa L.), protected a cold-sensitive enzyme (lactate dehydrogenase) from freezeinduced protein denaturation. The molecular chaperone activity of and oligomeric complex formation by CsHsp17.5 were unaffected by repeated freezing and thawing.

Complex formation of DcHsp17.7 under cold stress. One of the notable characteristics of sHSPs is their organization into large oligomeric complexes (Haslbeck et al., 2005). In the cellular environment, sHSPs are found in large complexes with molecular masses of 200 to $500 \mathrm{kDa}$. It is likely that the formation of these oligomeric complexes is closely related to the function of sHSPs. Previously, DcHsp17.7 was found in an oligomeric complex $(\approx 300 \mathrm{kDa}$ in size $)$ in carrot on exposure to high temperature (Kim and Ahn, 2009). In this study, to examine the conformational characteristics of DcHsp17.7 under cold stress, proteins from cold-stressed carrot leaf tissues and transformed $E$. coli expressing DcHsp17.7 were extracted under nondenaturing conditions and subjected to native-PAGE and immunoblot analyses. In carrot leaf, DcHsp17.7 was detected in two oligomeric complexes $(\approx 160$ and $240 \mathrm{kDa}$ in size $)$ starting from $3 \mathrm{~d}$ of $2{ }^{\circ} \mathrm{C}$ cold stress (Fig. 7A). Thereafter, the amount of the complexes significantly decreased at $5 \mathrm{~d}$, when only the $160 \mathrm{kDa}$ complex was present at a very low level. However, the two complexes containing DcHsp17.7 reappeared at $10 \mathrm{~d}$. It is possible that the oliomeric complexes include denatured substrate(s) of DcHsp 17.7. Furthermore, the substrates of DcHsp17.7 may be different in the two oligomeric complexes.

In our previous report, DcHsp17.7 was found in a larger oligomeric complex $(\approx 300$ $\mathrm{kDa}$ ) in heat-stressed carrot leaf tissue (Kim and Ahn, 2009). It is worth noting that in transformed E. coli expressing DcHsp17.7, on IPTG treatment, DcHsp17.7 was detected in similar-sized complexes between 300 and $450 \mathrm{kDa}$ (Fig. 7B). When bacterial cells were exposed to a low temperature $\left(2{ }^{\circ} \mathrm{C}\right)$, the complexes rapidly disappeared. However, under an extended cold stress condition, the oligomeric complexes containing DcHsp17.7 reappeared from $3 \mathrm{~d}$ and continued to accumulate up to $10 \mathrm{~d}$.

In both carrot leaf tissue and transformed E. coli cells expressing DcHsp17.7 (Figs. 3 and 4, respectively), SDS-PAGE followed by immunoblot analysis showed that DcHsp 17.7 was continuously present until the end of the cold treatment, suggesting that the disappearance of the oligomeric complexes is not (at least entirely) the result of denaturation of the protein, but rather is the result of becoming insoluble. The precise functional mechanism of conformational changes of plant sHSPs remains to be examined.

In this study, we showed that DcHsp17.7 can confer not only heat tolerance, but also cold tolerance. This suggests that DcHsp17.7 might be a promising candidate for generating transgenic crop plants with tolerance to both high and low temperature stresses. If successful, this would be very valuable when applied to physiological field conditions in which complex environmental stresses may exist.

\section{A.}

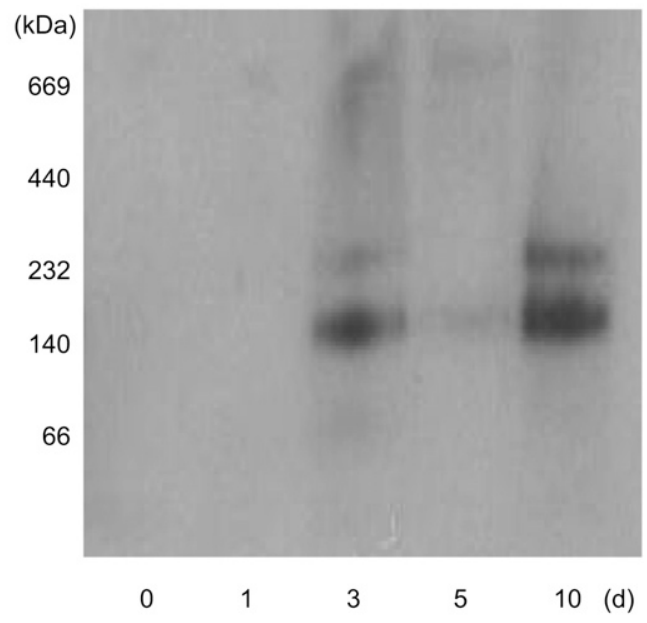

B.

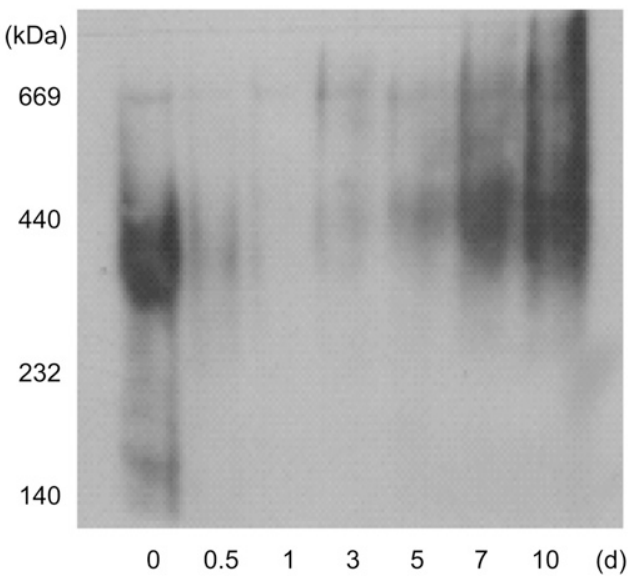

Fig. 7. Oligomeric complex formation by DcHsp 17.7 under cold stress. Proteins from cold-stressed $\left(2{ }^{\circ} \mathrm{C}\right.$ up to $10 \mathrm{~d}$ ) carrot leaf tissues (A) and transformed Escherichia coli cells expressing DcHsp17.7 (B) were obtained by homogenizing tissues and cells in extraction buffer containing no denaturing agent. A total of 30 and $25 \mu \mathrm{g}$ of carrot and E. coli protein, respectively, was resolved on $4 \%$ to $20 \%$ nativepolyacrylamide gels. Immunoblot analysis was performed using a polyclonal antibody raised against DcHsp17.7. 


\section{Literature Cited}

Ahn, Y.-J., K. Claussen, and J.L. Zimmerman. 2004. Genotypic differences in the heat-shock response and thermotolerance in four potato cultivars. Plant Sci. 166:901-911.

Ahn, Y.-J. and J.L. Zimmerman. 2006. Introduction of the carrot HSP17.7 into potato (Solanum tuberosum L.) enhances cellular membrane stability and tuberization in vitro. Plant Cell Environ. 29:95-104.

Bradford, M.M. 1976. A rapid and sensitive method for the quantitation of microgram quantities of protein utilizing the principle of protein-dye binding. Anal. Biochem. 72:248-254.

Coca, M.A., C. Almoguera, and J. Jordano. 1994. Expression of sunflower low-molecular-weight heat-shock proteins during embryogenesis and persistence after germination: Localization and possible functional implications. Plant Mol. Biol. 25:479-492.

Forreiter, C., M. Kirschner, and L. Nover. 1997. Stable transformation of an arabidopsis cell suspension culture with firefly luciferase providing a cellular system for analysis of chaperone activity in vivo. Plant Cell 9:2171-2181.

Haslbeck, M., T. Franzmann, D. Weinfurtner, and J. Buchner. 2005. Some like it hot: The structure and function of small heat-shock proteins. Nat. Struct. Mol. Biol. 12:842-846.

Jiang, C., J. Xu, H. Zhang, X. Zhang, J. Shi, M. Li, and F. Ming. 2009. A cytosolic class I small heat shock protein, RcHSP17.8, of Rosa chinensis confers resistance to a variety of stresses to Escherichia coli, yeast and Arabidopsis thaliana. Plant Cell Environ. 32:1046-1059.

Kang, L.W., S.B. Gabelli, J.E. Cunningham, S.F. O'Handley, and L.M. Amzel. 2003. Structure and mechanism of MT-ADPRase, a nudix hydrolase from Mycobacterium tuberculosis. Structure 11:1015-1023.

Kim, H. and Y.-J. Ahn. 2009. Expression of a gene encoding the carrot HSP17.7 in Escherichia coli enhances cell viability and protein solubility under heat stress. HortScience 44:866-869.

Lee, G.J., N. Pokala, and E. Vierling. 1995. Structural and in vitro molecular chaperone activity of cytosolic small heat shock proteins from pea. J. Biol. Chem. 270:10432-10438.

Lee, G.J., A.M. Roseman, H.R. Saibil, and E. Vierling. 1997. A small heat shock protein stably binds heat-denatured model substrates and can maintain a substrate in a foldingcompetent state. EMBO J. 16:659-671.

Lopez-Matas, M.-A., P. Nunez, A. Soto, I. Allona, R. Casado, C. Collada, M.-A. Guevara, C. Aragoncillo, and L. Gomez. 2004. Protein cryoprotective activity of a cytosolic small heat shock protein that accumulates constitutively in chestnut stems and is up-regulated by low and high temperatures. Plant Physiol. 134: 1708-1717.

Ma, C., M. Haslbeck, L. Babujee, O. Jahn, and S. Reumann. 2006. Identification and characterization of a stress-inducible and a constitutive small heat-shock protein targeted to the matrix of plant peroxisomes. Plant Physiol. 141:4760.
Malik, M.K., J.P. Slovin, C.H. Hwang, and J.L. Zimmerman. 1999. Modified expression of a carrot small heat shock protein gene, hsp17.7, results in increased or decreased thermotolerance. Plant J. 20:89-99.

Nover, L., K.D. Scharf, D. Gagliardi, P. Vergne, E. Czarnecka-Verner, and W.B. Gurley. 1996. The hsf world: Classification and properties of plant heat stress transcription factors. Cell Stress Chaperones 1:215-223.

Soto, A., I. Allona, C. Collada, M.-A. Guevara, R. Casado, E. Rodriguez-Cerezo, C. Aragoncillo, and L. Gomez. 1999. Heterologous expression of a plant small heat-shock protein enhances Escherichia coli viability under heat and cold stress. Plant Physiol. 120:521-528.

Sun, W., M. van Montagu, and N. Verbruggen. 2002. Small heat shock proteins and stress tolerance in plants. Biochim. Biophys. Acta 1577:1-9.

Thomashow, M.F. 1999. Plant cold acclimation: Freezing tolerance genes and regulatory mechanisms. Annu. Rev. Plant Physiol. Plant Mol. Biol. 50:571-599.

Vinocur, B. and A. Altman. 2005. Recent advances in engineering plant tolerance to abiotic stress: Achievements and limitations. Curr. Opin. Biotechnol. 16:123-132.

Yeh, C.H., P.F. Chang, K.W. Yeh, W.C. Lin, Y.M Chen, and C.Y. Lin. 1997. Expression of a gene encoding a $16.9-\mathrm{kDa}$ heat-shock protein, Oshsp16.9, in Escherichia coli enhances thermotolerance. Proc. Natl. Acad. Sci. USA 94: 10967-10972. 